\title{
Perfil Higiênico de Carne Bovina Moída Comercializada na Cidade do Rio de Janeiro e Adjacências, Estado do Rio de Janeiro, Brasil
}

A clean profile of the grounded bovine flesh meat commercialized in Rio de Janeiro city plus some areas around it, Rio de Janeiro State, Brazil

$$
\begin{aligned}
& \text { Professora Mestre Maria Célia Ferreira (Ciências Biológicas - FTESM) } \\
& \text { Professor Doutor Antonio Neres Norberg (Medicina - UNIFOA e UNIG) } \\
& \text { antonio.norberg@foa.org.br }
\end{aligned}
$$

Professora Especialista Ana Carolina Torres

(Enfermagem - FTESM) Mestranda da Universidad Autónoma de Asunción, Paraguay Ana.biovet@bol.com.br

\author{
Professor Mestre Paulo César Ribeiro (Odontologia - UNIG) \\ ribeiroribeirop@uol.com.br \\ Professor Fabiano Guerra Sanches \\ Mestrando da Universidad Autónoma de Asunción, Paraguay \\ fab.gs@bol.com.br \\ Professora Doutora Margareth Maria de Carvalho Queiroz \\ (Medicina - UNIG, FIOCRUZ) \\ mmcqueiroz@ioc.fiocruz.br \\ Professor Doutor Raimundo Wilson de Carvalho \\ (Fisioterapia - UNIFOA, FIOCRUZ, bolsista CNPq) \\ raimundo.carvalho@foa.org.br, raimundo.carvalho@pesquisador.cnpq.br
}

\section{Resumo}

Foi avaliada a ocorrência de soro-grupos do gênero Salmonella em 150 amostras de carne bovina moída comercializada em açougues da cidade do Rio de Janeiro e adjacências. Após as coletas, as amostras de carne foram mantidas sob refrigeração até serem feitas as semeaduras em Tetrationate Broth. Posteriormente foram repicadas em Eosin-MethilenBlue Agar e Salmonella-Shigella-Agar. O crescimento obtido foi identificado através de caracteres morfológicos, culturais, provas bioquímicas e sorológicas. $O$ resultado mostrou que $52 \%$ das amostras estavam contaminadas por Salmonelas. Os soro-grupos B e D apresentaram as maiores incidências e nenhuma amostras apresentou-se contaminada pelo soro-grupo A, soro-grupo exclusivo de humanos

Palavra-chave: Salmonella spp.; Carne Bovina; Toxinfecção Alimentar.

Abstract 
The occurrence of serum-groups of the Salmonella type was appraised in 150 samples of grounded bovine flesh meat commercialized in Butcheries from the Rio de Janeiro city plus some areas around it. After the collected works, the samples of flesh meat were kept in refrigeration until the sowing in Tetrationate Broth got prepared. Later they were chopped once more in Eosin-Methilen-Blue-Agar and Salmonella-Shigella-Agar. The achieved growth was identified through morphology and culture signs, plus biochemistry and serum experiments. The result showed that $52 \%$ of the samples were infected by Salmonellas. The serum-groups B and D presented the main incidences and none of the samples got infected by the serum-group A, a restricted serum-group to humans.

Key-words: Salmonella spp.; Bovine Flesh Meat; Alimentary Toxicity.

\section{Introdução}

O gênero Salmonella possui distribuição mundial, é composto por aproximadamente 2200 espécies, sendo um dos mais importantes na família Enterobacteriaceae. São bactérias entéricas que habitam o aparelho digestivo de animais de sangue quente e frio, dentre elas, destacam-se as das espécies S. paratyphi (soros-grupo A e B), S. cholerasuis (soro-grupo C) S. typhi (soro-grupo D), S. enteritidis, S.anatum (soro-grupo E) e S. typhimurium como as principais responsáveis por surtos de toxinfecções alimentares (LACEYY, 1993; JAKABI et al., 1999; FRANCO \& LANDGRAF, 2003). Surtos de enfermidades transmitidas por alimentos passaram a ser relatados nos Estados Unidos, onde se estimou para o início da última década do século passado a ocorrência de 6,5 milhões de casos com 9000 óbitos (CDC, 1993; PERESI et al., 1998), e em vários países da Europa, desde o final da década de 70 (SCUDERI et al., 1996). Aserkoff \& Schroeder (1970) inferiram que, apesar das medidas de higiene e o controle bacteriológico adotado em matadouros, registros de toxinfecções alimentares continuam aumentando. Sabe-se que a carne, mesmo que seja obtida de animais sadios, é um veículo potencial de contaminantes de natureza biológica, física e química (SANTOS et al., 2000), nas diversas fases de processamento, que vão desde a sangria até o abate do animal, nas feiras livres, nos açougues e supermercados, com a agravante de que durante todo o seu processamento, é manipulada por pessoas que, por falta de orientação ou negligência, colaboram com a baixa qualidade do produto que chega aos consumidores (OLIVEIRA et al., 2002; FAUSTINO et al., 2003; PIGATTO \& BARROS, 2003). Hofer et al. (1998) isolaram de matérias-prima e de ração para ave além de outras amostras acumuladas entre 1979 e 1991, oriundas de sete regiões distintas do Brasil, 151 sorovares de salmonelas diferentes. O objetivo do presente manuscrito foi o de avaliar a presença de salmonelas em carne bovina na cidade do Rio de Janeiro e adjacências, além de identificar os sorogrupos envolvidos em tal contaminação.

\section{Material e Métodos}

O material estudado constituiu-se de 150 amostras de carne bovina moída, adquirida em diferentes açougues da cidade do Rio de Janeiro e adjacências, Niterói (Adjacência 1), Duque de Caxias, Nova Iguaçu, Paracambi, São João de Meriti, Vassouras e Volta Redonda (Adjacência 2). Foram mantidas sob refrigeração até a semeadura nos seguintes meios 
artificiais de cultura: Salmonella-Shigella (SSAgar), Eosin-Metheilen (EMBAgar), Nutrient Agar, SIM Médium; além desses, foram utilizados ainda outros meios para identificação por provas bioquímicas, com os substratos: dulcitol, xilose, arabinose, malonato, citrato e lisina, além da observação da mobilidade, produção de gás sulfídrico, indol e oxidase.

Efetuou-se a semeadura de aproximadamente cinco gramas de carne moída em garrafas de Roux contendo 100ml de Tetrationate Broth, após incubação de 24 horas a $37^{\circ} \mathrm{C}$, procedeu-se o repique nos meios Eosin-Methilen-Blue Agar e Salmonella-Shigella Agar e nova incubação por mais 24 horas a $37^{\circ} \mathrm{C}$. O crescimento obtido foi analisado observando se a morfologia das colônias e as características morfotintoriais, através de esfregaços corados pelo método de Gram e modificado por Koppelof-Beerman.

A partir das colônias isoladas foram efetuadas provas bioquímicas, incluindo provas de fermentação do dulcitol, xilose, arabinose, utilização do citrato e malonato, descarboxilação da lisina, observação da mobilidade, produção de gás sulfídrico, indol e oxidase.

As bactérias com características do gênero Salmonella foram submetidas à identificação por provas sorológicas. Para tal, preparou-se suspensões antigênicas a partir do crescimento de 18 horas a $37^{\circ} \mathrm{C}$, de amostras lisas previamente selecionadas em Nutrient Agar inclinado, conforme os autores acima recomendaram. O método sorológico empregado foi o da aglutinação rápida em lâmina, utilizando-se anti-soros para os grupos A, B, C, D e E.

\section{Resultados}

Neste trabalho se demonstrou a ocorrência de soro-grupos de salmonelas em carne bovina comercializada em açougues da cidade do Rio de Janeiro e municípios adjacentes. Do total de 150 amostras estudadas, 78 (52\%) estavam contaminadas com salmonelas, sendo que a região correspondente à adjacência 2, ou seja, os municípios de Duque de Caxias, Nova Iguaçu, Paracambi, São João de Meriti, Vassouras e Volta Redonda apresentou a maior freqüência relativa, porém sem diferença significativa $(p>0,05)$ (Tabela1).

A distribuição por soro-grupo das salmonelas isoladas, demonstrou predominância dos soros-grupo B e D ( $<<0,05)$, sendo que em 15,4\% das amostras ocorreu contaminação simultânea pelos dois soros-grupo acima (Tabela 2). 


\begin{tabular}{|c|c|c|c|c|}
\hline \multirow[t]{2}{*}{ Região de origem das amostras } & \multirow{2}{*}{$\begin{array}{l}\text { Amostras } \\
\text { examinadas }\end{array}$} & \multicolumn{3}{|c|}{ Amostras contaminadas } \\
\hline & & Positivas & $\%$ regional & $\%$ glotal \\
\hline Rio de Janeiro & 50 & 25 & 50 & 16,7 \\
\hline Niteroi (Adjacencia 1) & 50 & 24 & 48 & 16 \\
\hline $\begin{array}{l}\text { Duque de Caxias, Nova Iguaçu, } \\
\text { Paracambi, Sł̇o Joåo de Meriti, } \\
\text { Vassouras e Volta Redonda (adjacência } \\
\text { 2) }\end{array}$ & 50 & 29 & 58 & 19,3 \\
\hline Total & 150 & 78 & 52 & 100 \\
\hline
\end{tabular}

Tabela 1: Número de amostras de carne bovina examinada, oriundas do município do Rio de Janeiro e adjacências. Teste binomial duas proporçס̋es $(p<0,05)$

\begin{tabular}{cccc}
\hline Soro-grupo & Número de amostras & \\
positivas & 30 & $\%$ & Média \pm Desvio padră \\
B & 4 & 58,4 & $10 \pm 2,64 *$ \\
C & 24 & 30,8 & $1,3 \pm 1,50$ \\
D & 7 & 9 & $8 \pm 3 *$ \\
E & 12 & 15,4 & $2,3 \pm 0,6 \mathrm{~b}$ \\
BD & 1 & 1,3 & $1,3 \pm 2 b$ \\
CB & 78 & 100 & $\ldots$ \\
Total & 78 & $\ldots$
\end{tabular}

Tabela 2: Distribuição dos soro-grupos de salmonelas identificados e isolados das amostras de carne bovina moída no município do Rio de Janeiro e adjacências. Teste Binomial para uma proporção, p<0,05; proporção do evento em relação às amostras foi de 0,17 . *Letras iguais sem diferença significativa.

\section{Discussão}

As salmonelas são consideradas as bactérias mais freqüentes em surtos de doenças de origem alimentar, em diversos países, inclusive Brasil (SCUDERI et al., 1996; PERESI et al., 1998) por serem consideradas microrganismos de ampla disseminação, são capazes de se difundirem com facilidade pelos alimentos a partir de um produto contaminado (LEITÃO, 1988; OLIVEIRA et al., 2000). As doenças causadas por elas costumam ser subdivididas em três grupos, a febre tifóide, causada por $S$. typhi, as febres entéricas, causadas por $S$. paratyphi e as enterocolites ou salmoneloses, causadas pelas demais salmonelas. A primeira somente acomete o homem, e normalmente é transmitida através da água e de alimentos contaminados com material fecal humano (ACHA \& SZIFRES, 1986; ALMEIDA et al., 2000). A prevalência de 52\% aferida nas amostras obtida, sugere que nossos dados refletem o mencionado pelos autores acima e ainda sejam correlatos aos dados obtidos nos Estados Unidos da América entre 1973 e 1987 (BEAN et al., 1990), onde se aferiu que ocorriam causadores de toxinfecções alimentares em um alto percentual de indivíduos e em sua maioria oriundos de produtos animais. Lá foi constatado que as infecções estavam associadas ao consumo de carne crua ou mal cozidas por significante parcela da comunidade. Calzada et al., (1984) em estudo de sorotipos de salmonelas comentaram a disseminação de $S$. agona a partir de farinha de peixe e o aumento de seu isolamento em nosso meio a partir de material humano, alimento, praia e esgoto dentre outros. No que se refere ao esgotamento sanitário, as regiões estudadas possuem menos de $60 \%$ de seu território com esgoto tratado (MENDES et al., 2005), o que ratifica a 
afirmativa sussomencionada. Outro resultado que se considera de destaque se relaciona com a ausência do soro-grupo A nas amostras analisadas, este em especial, congrega espécies de salmonelas exclusivas de seres humanos, sendo assim se revela, através desta amostra, não haver contaminação oriunda de portadores humanos. Considerando este achado, ratifica-se o encontro de Hormaeche (1939) no Uruguai, onde infecções graves, além das toxinfecções comuns, sobretudo em crianças, ocorreram em função da contaminação por consumo de alimentos crus contaminados. Seguindo-se esta linha de raciocínio, Schthorst et al. (1976) destacaram a presença de altos índices de contaminação por salmonelas em determinados alimentos, podendo alcançar taxas de até $70 \% \mathrm{em}$ produtos como ostras, peixes e rãs, considerando assim a notável contaminação do ambiente.

A freqüência de contaminação pelos soros-grupo B e $\mathrm{D}$, onde as espécies $S$. typhimurium e $S$. dublin são contaminantes freqüentes, corroborou essa situação, destacando a possibilidade de contaminação através da manipulação da carne fresca. Devese lembrar que essa manipulação se dá desde o abatedouro até a comercialização, havendo assim ampla possibilidade de contaminação.

Segundo levantamento feito por Rombouts \& Kampelmacher (1973), 7500 pessoas na Holanda estavam infectadas por Salmonella spp., naquela altura, eles estimaram que, dada à facilidade de transmissão do agente, pelo menos 20 milhões de casos deveriam estar ocorrendo no mundo. Atualmente, considerando o aumento da população mundial e a ocorrência de fatores que facilitam essa transmissão, pode-se inferir que a quantidade de casos deve ter triplicado. Essa indicação é facilmente verificada acompanhando se as estatísticas atuais sobre o problema, as quais indicam ser esta uma das mais graves dificuldades da saúde coletiva mundial, a Organização Mundial de Saúde revelou que a taxa de mortalidade atrelada à infecção alcançou o índice de $0,4 \%$, segundo eles, este índice é considerado significativo para infecções de origem bacteriana.

Em manuscrito recente Oliveira et al. (2005) apontaram para o uso do cloranfenicol como droga de escolha no tratamento de salmonelose sistêmica em humanos e, desde a década de 70, tem tido seu uso diminuído na terapia de animais utilizados para produção de alimentos, uma vez que, vem apresentando resistência. White et al. (2001) analisando 200 amostras de carne bovina, encontraram salmonelas em 41 delas, identificando 13 sorotipos diferentes, isso correspondeu a $20 \%$ do total examinado. Naquela oportunidade, as amostras isoladas foram submetidas a testes de sensibilidade a antibióticos e a quimioterápicos, resultando na verificação de resistência de $80 \%$ a pelo menos um dos antibióticos utilizados e de $53 \%$ a pelo menos três desses antibióticos. Os mesmos registros relataram, ao ser testado o ceftriaxone, antibiótico considerado de escolha para o tratamento de salmoneloses. Com base nesses resultados, os autores concluíram que a resistência adquirida aos antimicrobianos deveria estar relacionada ao uso imprudente de antibióticos adicionados à ração para se evitar o relatado por Hofer et al. (1998). Segundo os fabricantes de ração, esta é uma prática necessária para reduzir o número de patógenos presentes nas fazendas, e conseqüentemente evitar infecções em manipuladores de alimentos. Entretanto, ocorre que, os microrganismos que adquiriram resistência continuam a contaminar a carne e ser transmitidas para os seres humanos (ABRAHÃO et al. 2005).

Embora não tenha sido objeto da nossa pesquisa, indica-se a possibilidade desse quadro poder existir em nosso meio, tanto quanto em outras partes do mundo, fator que através dos processos de importação e exportação difundirão ainda mais o problema. 
Por fim, a possibilidade de se traçar um perfil dos sorotipos prevalentes e seu real potencial em uma comunidade é instrumento importante na elaboração de um programa de controle eficaz através de sorotipagem e fagotipagem das cepas de Salmonella sp. e podem auxiliar no controle da disseminação deste agente responsável por agravos importante tanto no homem quanto em animais (LÍRIO et al., 2006).

\section{Referências}

ABRAHÃO, R.M.C.M.; NOGUEIRA, P.A.; MALUCELLI, M.I.C. 2005. O comércio clandestino de carne e leite no Brasil e o risco de transmissão da tuberculose bovina e de outras doenças ao homem: um problema de saúde pública. Arch. Vet. Science. 10: 117.

ACHA, P.N. \& SZYFRES, B. 1986. Zoonoses y enfermidades transmissibles comunes al hombre y los animales. $2^{\mathrm{a}}$. Ed. Washington, Organização Panamericana de Saúde. 158-166.

- ALMEIDA, A.Z.C.; PERESI, J.T.M.; CARVALHO, I.S.; RODRIGUES, E.A.C.; MARQUES, D.E.; TAVECHIO, A.T.; FERNANDES, S.A. 2000. Salmonella: sorotip0os identificados na região de São José do Rio Preto-SP, no período entre 1990 e 1999. Rev. Inst. Adolfo Lutz 59: 33-37.

- ÁVILA, C.R.; GALlO, C.R. 1996. Pesquisa de Salmonella spp. em leite cru, leite Pasteurizado tipo C e Queijo "Minas Frescal" comercializados no município de Piracicaba-SP. Sci. agric. 53: 159-163.

- ASERKOFF, B. \& SCHROEDER, S.A. 1970. The problem of Salmonellae in foods. Am. J. Epid., 92: 13-16.

- BEAN, N.H. \& GRIFFIN, P.M. 1990. Footborne Disease outbreaks in the United States, 1973-1987: Pathogens, Vehicles and Trends. J. Food Protection, 53: 804-817.

- CALZADA, C.T.; NEME, S.N.; IRINO, K.; KANO, E.; DIAS, A.M.G.; FERNANDES, S.A.; VAZ, T.M.I.; PESSÔA, G.V.A. 1984. Sorotipos de Salmonella identificados no período 1977-1982, no Instituto Adolfo Lutz, São Paulo, Brasil. Rev. Inst. Adolfo Lutz 44: $1-18$.

- CENTER FOR DISEASE CONTROL (CDC). 1993. Outbreak of Salmonella enteritidis associated with homemade ice cream. Flórida. MMWR, 42: 793-797. 
FALCÃO, D. P.; SUASSUNA, I.; SUASSUNA, I.R. 1979. Avaliação do meio "Agar xilose lisina verde brilhante" no isolamento de Salmonella. Rev. Saúde Pública 13: 4346.

- FAUSTINO, M.A.G.; LIMA, M.M.; ALVES, L.C.; SANTOS, A.L.G. SANTANAM, V.L.A. 2003. Causas de condenação à inspeção sanitária em abatedouro de bovinos da cidade de Valença, Rio de Janeiro. Hig. Alimentar 17: 32-35.

- FRANCO, B.D.G.M.; LANDGRAF, M. 2003. Microbiologia dos alimentos. São Paulo: Ed. Atheneu, 55-56.

- HOFER, E.; SILVA-FILHO, S.J.; REIS, E.M.F. 1998. Sorovares de Salmonella isolados de matérias-primas e de ração para aves no Brasil. Pesq. Vet. Bras. 18: 21-27.

- HORMAECHE, E. 1939. Patologia y epidemiologia de lãs salmoneloses infantiles. Arch. Ped. Urug. 10: 443.

- JAKABI, M. et al. Observações laboratoriais sobre surtos alimentares de Salmonella sp. Ocorridos na grande São Paulo no período de 1994 a 1997. Rev. Inst. Adolfo Lutz 58: 47-51, 1999.

- LACEYY, R.W. 1993. Food-borne bacterial infections. Parasitology 107 (suppl): 575593.

- LEITÃO,M.F.F. 1988. Microbiologia de alimentos. In: ROITMAN, I.; TRAVASSOS, L.R.; AZEVEDO, J.L. Tratado de microbiologia. Ed. Manole 2: 70-75.

- LÍRIO, V.S.; SILVA, E.A.; STEFONI, S.; CAMARGO, D.; RECCO, E.A.P.; MALUF, Y.T.; MIYAZAWA, T.T.; NEVES, D.V.D.A.; OLIVEIRA, V.M. 2006. Freqüência de 17 sorotipos de Salmonela isolados em alimentos. Rev. Hig. Alimentar 20: 69-70.

- MENDES, E.C.; SILVA, S.S.; FONSECA, E.A.L.T.; SOUZA, H.R.R.; CARVALHO, R.W. 2005. A Neurocisticercose humana na Baixada Fluminense, Estado do Rio de Janeiro, Brasil. Arq. Neuro-Psiquiatr. 63: 907-913.

- OLIVEIRA, D.D. AND SILVA, E.N. 2000. Salmonela em ovos comerciais: ocorrência, condições de armazenamento e desinfecção da casca. Arq. Bras. Med. Vet. Zootec. 52: 655-661. 
- OLIVEIRA, N.M.S.; NASCIMENTO, L.C.; FIORINI, J.E. 2002. Isolamento e identificação de bactérias facultativas mesofílicas em carnes frescas bovinas e suínas. Rev. Hig. Alimentar 16: 68-74.

- OLIVEIRA, S.D.; FLORES, F.S.; SANTOS, L.R.; BRANDELL, A. 2005. Antimicrobial resistence in Salmonella enteritidis strains isolated from broiler carcasses, food, human and poutry-related samples, Int. J. Food Microbiology 97: 297305.

- PERESI, J.T.M.; ALMEIDA, I.A.Z.C.; LIMA, S.I.; MARQUES, D.F.;RODRIGUES, E.C.A.; FERNADES, S.A.; GELLI, D.S.; IRINO, K. 1998. Surtos de enfermidades transmitidas por alimentos causados por Salmonella enteritidis. Rev. Saúde Pública 32: 477-483.

- ROMBOUTS, F.M.; KAMPELMACHER, E.H. 1973. Voedsevelveriftigingen. Natur. Technieck 41: 2-16.

- SANTOS, D.M.S.; BERCHIERI J.A.; FERNANDES, S.A.; TAVECHIO, A.T.; AMARAL, L.A. 2000. Salmonella em carcaças de frango congeladas. Pesq. Vet. Bras. 20: 39-42.

- SCUDERI, G.; FANTASIA, M.; FILETICI, E.; ANASTÁSIO, M.P. 1996. Foodborne outbreaks caused by Salmonella in Italy among 1991 and 1994. Epidemiol. Infect. 116: 257-265.

- SCHTHORST, M.V.; NORTHOLT, M.J.; KAMPELMACHER, E.H.; NOTERMANS, S.A. 1976. A survey of Salmonella contamination in animal feeds. J. Hig. Camb. 3 : 66-67.

- WHITE, D.G.; ZHAO, S.; SUDLER, R.; FRIEDMAN, S.; McDERMOTT, P.F.; WAGNER, D.D.; MENG, J. 2001. The isolations of antibiotic-resistant salmonella from retail ground meats. N. Engl. J. Med. 345: 1147-1154.

Informações bibliográficas:

Conforme a NBR 6023:2002 da Associação Brasileira de Normas Técnicas (ABNT), este texto científico publicado em periódico eletrônico deve ser citado da seguinte forma: FERREIRA, M. C.; NORBERG, A. N.; TORRES, A. C.; RIBEIRO, P. C.; SANCHES, F. G.; QUEIROZ, M. M. C.; CARVALHO, R. W.. Perfil Higiênico de Carne Bovina Moída Comercializada na Cidade do Rio de Janeiro e Adjacências, Estado do Rio de Janeiro, Brasil. Cadernos UniFOA, Volta Redonda, ano 1, n. 2, nov. 2006. Disponível em: <http://www.unifoa.edu.br/pesquisa/caderno/edicao/02/83.pdf > 